\title{
CONSUMO, PERSPECTIVAS MERCADOLÓGICAS E SOCIOCULTURAIS EM FOCO
}

Eneus Trindade ${ }^{1}$

Clotilde Perez ${ }^{2}$

Esta edição, Volume 7 Número 2 da Revista Signos do Consumo, traz discussões que transitam entre publicidade, marca, consumo, mídia e discurso. Tais articulações levam em conta perspectivas mercadológicas, mas também socioculturais e ideológicas, principalmente nas referências ao discurso político. Integra a diversidade de lócus acadêmico dos autores, com contribuições nacionais e internacionais, bem como privilegia a variedade de abordagens teóricas e metodológicas, como veremos na apresentação dos textos a seguir.

É nesse espírito que surge o primeiro artigo intitulado “As origens das marcas e da publicidade moderna: As campanhas publicitárias de sabões e sabonetes" de António Machuco Rosa, Professor Associado da Faculdade de Letras da Universidade do Porto, Portugal, que analisa o surgimento das marcas e da publicidade moderna por meio das campanhas publicitárias de sabões e sabonetes no início do século XX. Para tanto, o autor analisa as campanhas de Woodbury's e de Lux, sublinhando o papel que a agência J. Walter Thompson teve na construção publicitárias dessas marcas. Mostra-se que no início do século XX já existiam duas grandes tendências na criação de campanhas publicitárias, a chamada publicidade "reason-why" e a publicidade "emocional". O autor apresenta ao final como essas duas tendências estão associadas a duas concepções sobre o papel das marcas no mercado e na sociedade. Importante contribuição para o entendimento sobre o papel da publicidade, atualmente no sentido de uma hiperpublicidade, na construção das marcas.

\footnotetext{
${ }^{1}$ Professor Livre Docente do Departamento de Relações Públicas, Propaganda e Turismo da ECA/USP. Docente do PPGCOM/ECA/USP na área de teoria e pesquisa em comunicação e Vice-coordenador do Grupos de Estudos Semióticos em Comunicação, Cultura e Consumo CNPq/ECA/USP. Possui pósdoutorado em Antropologia Visual pela Universidade Aberta de Portugal. Doutor e Mestre em Comunicação pela ECA/USP.

${ }^{2}$ Professora Livre Docente em Ciências da Comunicação do Departamento de Relações Públicas, Propaganda e Turismo da ECA/USP. Docente do PPGCOM/ECA/USP na área de interfaces sociais da comunicação. Coordenadora dos Grupos de Estudos Semióticos em Comunicação, Cultura e Consumo $\mathrm{CNPq} / \mathrm{ECA} / \mathrm{USP}$. Possui pós-doutorado em Comunicação pela Universidade de Murcia-Espanha. Doutora em Comunicação e Semiótica pela PUC-SP, Mestre em Administração pela PUC-SP.
} 
"A influência da transgressão e da raiva do consumidor na avaliação de provedores de serviços”, de Susi D’Almeida Garrett, da Faculdade Estácio de Sá, Curitiba e também da FACEAR e Paulo H. M. Prado, da Universidade Federal do Paraná, é um texto decorrente da pesquisa teórica sobre temas como raiva, transgressão, violação de conduta etc., bem como empírica, de natureza causal, realizada na cidade de Curitiba e região. O texto discorre sobre a influência da emoção da raiva dos consumidores, decorrente de uma situação de transgressão (violação de conduta ou falha), na percepção de qualidade do relacionamento consumidor-empresa, mas também analisa a eficiência das ações de recuperação implementadas. Como síntese conclusiva evidencia que a raiva surgiu como a emoção mais sentida pelos participantes após as falhas no serviço, e depois das ações de recuperação, as médias gerais de todas as emoções negativas caíram, em especial, justamente as médias da raiva. Um importante exemplo de estudo na linha do "como não fazer", tão exíguos nas pesquisas em Comunicação e Consumo.

A terceira contribuição é de Nathalia Santos Andrijic, publicitária da ECA USP e de Leandro Leonardo Batista, professor do PPGCom ECA USP e pesquisador do GESC3 - Grupo de Estudos Semióticos em Comunicação Cultura e Consumo, com o texto "Causas sociais e as novas plataformas de comunicação: Teorias, viabilidade e práticas". Os autores analisam como as causas sociais e suas mensagens podem ser relacionadas às mídias sociais digitais. Inicialmente investigam as teorias a esse respeito, mas também as práticas de mercado e a viabilidade da relação em prol da melhor comunicação dessas mensagens, explorando suas vantagens e desvantagens. Como encaminhamento conclusivo, os autores revelam que a abordagem do Marketing se mostrou mais benéfica aos resultados comunicacionais pretendidos frente a outras opções analisadas. Vale conferir.

Tobias Oliveira Camargo, mestre em Design Estratégico, pela Universidade do Vale do Rio dos Sinos - UNISINOS, RS, nos apresenta o texto "O consumo - Revisão teórica sobre as possíveis razões do "ir às compras" por meio de infográfico", que manifesta como foco a discussão teórica preliminar sobre a sociedade de consumo, com uma destacada retomada histórica, além de pôr em debate autores e teorias que se relacionam na construção deste campo. De forma bastante interessante, o autor apresenta um infográfico ao final do texto, em que propõe uma síntese genérica com base nas relações encontradas entre as teorias e os autores estudados. A pesquisa 
bibliográfica aponta que a descoberta e expressão do self, a marcação social, a transferência de significados para os artefatos de acordo com cada cultura e rituais são entendidas como possíveis causas que poderiam levar à atividade de consumo.

"A análise sociosemiótica do discurso político-partidário" é o título do artigo escrito pelos autores Rosália Maria Netto Prados, professora da Universidade de Mogi das Cruzes e da Fatec - SP, em parceria com Moacir Wuo, biólogo, doutor em Psicologia e professor da Universidade de Mogi e Luci Mendes de Melo Bonini, doutora em Comunicação pela PUC SP e também professora da Universidade de Mogi no programa de pós-graduação em Políticas Públicas. Os autores propõem identificar, descrever e analisar a estrutura narrativa de um discurso político partidário, especificamente no editorial de uma publicação periódica de um partido político brasileiro, surgido nos anos 80 . O objeto de estudo foi o editorial na página 2 da edição número 15 da revista Pensar Verde, publicação patrocinada pela Fundação Verde Herbet Daniel, ligada ao Partido Verde. O periódico encontra-se em uma plataforma de aceso aberto para publicação de livros e revistas intitulada ISSU. O texto detalha o estudo do discurso, utilizando-se para tanto da análise Sociossemiótica. Como se trata de um estudo de discursos sociais, cujos sujeitos enunciador e enunciatário são coletivos, ou grupos sociais, ou partidos políticos, o método de análise empregado é adequado, o que permitiu a qualidade e a pertinência das conclusões apresentadas pelos autores.

Cláudio de Musacchio e Jociane Marchesan Oling, são os autores do artigo "A publicidade televisiva e o consumidor infantil do ensino fundamental no município de Ijuí/RS”. O texto analisa alguns aspectos da propaganda televisiva e sua relação com o consumo infantil, suas estratégias de recepção, processos de persuasão e hábitos culturais. Para tanto, empregou pesquisa de campo qualitativa com crianças entre oito e dez anos no Município de Ijuí, localizado no Estado do Rio Grande do Sul. O aporte teórico teve a contribuição epistemológica de pensadores que auxiliam na reflexão acerca do consumo contemporâneo. Já os resultados empíricos indicam que a criança adquire a capacidade de filtrar mensagens e influenciar nas decisões familiares para consumir.

"A participação da publicidade na socialização e na formação moral da criança", é o texto de autoria de Lyvia Tascone, mestre em Comunicação e Informação pela École Normale Supérieure de Lyon, França. O artigo busca contribuir com o atual debate 
sobre o tema criança e publicidade, fundamentado em grupos de discussão realizados com crianças no Brasil e na França, sendo, portanto, um estudo comparativo. A análise da complexa relação existente entre as crianças e a publicidade permitiu a descoberta de um pensamento crítico das crianças em relação à publicidade em ambos os países. No entanto, esse pensamento não restringe a participação da publicidade na socialização e formação moral das crianças, mas evidencia um intercâmbio ativo e complexo, o que aponta para a necessidade de um investimento aprofundado em pesquisas nessa área, que possam ampliar o entendimento e clarificar caminhos para uma práxis publicitária transparente, responsável e continuamente criativa.

Esta edição da Signos finaliza com a resenha do livro "O mundo codificado: por uma filosofia do design e da comunicação" de Vilém Flusser, elaborada por Larissa Drigo Agostinho, professora de Filosofia da ESPM e doutora em Literatura Francesa pela Universidade de Paris IV, Sorbonne, França. O título por ela eleito já sintetiza a essência da proposição de autor nesse texto, publicado em 2013 "A filosofia da comunicação de Flusser ou por uma nova imaginação".

Boa leitura!

Os Editores 